\title{
Effects of properties of metal-contaminated soils on bacterial bioluminescence activity, seed germination, and root and shoot growth
}

\author{
II-Mo Kang ${ }^{1}$ and In Chul Kong ${ }^{2^{*}}$
}

\begin{abstract}
This study examined the effects of several factors (metal contents and soil properties) on bacterial bioluminescence activity, seed germination and root/shoot growth of Lactuca in metal-contaminated soils. Each bioassay showed different sensitivities to extractants of soil samples. Average sensitivities of the bioassay were in the following order: root growth $>$ bioluminescence $\geq$ shoot growth $\geq$ seed germination. Both total and weak acid-extracted metal contents showed no observable correlations with the activity of any bioassays $\left(r^{2}<0.279\right)$. However, reasonable correlations were observed between the bioluminescence activity and organics $\left(r^{2}=0.7198\right)$ as well as between root growth and CEC $\left(r^{2}=0.6676\right)$. Effects of soils were difficult to generalize since they were dependent on many factors, such as soil properties, metal contents, and the organism used in each test. Nonetheless, these results indicated that a battery of bioassays is an effective strategy for assessment of contaminated soils. Furthermore, specific soil factors were shown to more influence on soil toxicity, depending on the type of bioassay.
\end{abstract}

Keywords: Bioassay, Bioluminescence, Seed germination, Root/shoot growth, Soil extractants

\section{Background}

Metals are common contaminants in many parts of the environment and are responsible for numerous environmental and health problems (Shivhare and Sharma 2012). Metals are one of the most resistant contaminants affecting ecosystems due to their non-biodegradability and possible toxicity. For example, metalloid arsenic is one of the most toxic contaminants found in soil, which is produced by many industrial activities (Yi et al. 2007; Ravenscroft et al. 2009). Generally, soil pollution by metals is evaluated by chemical analysis of the concentrations of metals (Agnieszka et al. 2014). Soil monitoring in Korea is also based mainly on the maximum permissible chemical contents of two standards: concern standard and countermeasure standard. However, chemical data alone

\footnotetext{
*Correspondence: ickong@ynu.ac.kr

${ }^{2}$ Department of Environmental Engineering, Yeungnam University,

Kyungbuk 38541, Korea

Full list of author information is available at the end of the article
}

such as concentrations of contaminants are not sufficient to assess toxic effects on the ecosystem, as they do not provide information on the effects of contaminants on biota. Therefore, to assess risk of contaminated environments, chemical methods should complement existing biological and toxicological methods (Molnar et al. 2005; Leitgib et al. 2007).

Toxicity evaluation of contaminated environments has gained widespread attention over the past two decades (Banks and Schultz 2005). Toxicity bioassays provide information on the detection of contaminated chemicals as well as the bioavailability of substances that may harm the environment (Alvarenga et al. 2008). However, no individual bioassay can provide a true estimation of chemical toxicity since none has uniform sensitivity to all pollutants. Therefore, evaluation based on individual toxicity levels is of limited benefit unless it can be correlated with other data. Plaza et al. (2010) reported that it is essential to select appropriate organisms to test for different taxonomic groups and candidates representing 
different links of the trophic chain because organisms show variable sensitivity to different substances. To test chemical toxicity, various organisms such as bacteria, algae, protozoa, plants, and fish are utilized (US EPA 1993). In addition to whole organisms, several key metabolic processes of organisms, specifically enzyme activity or biosynthesis, and bacterial bioluminescence, have been used to assess toxicity of environmental systems. Plant processes have been performed for several different types of toxicity studies involving in environmental biomonitoring (Di Salvatore et al. 2008). For example, seed germination primarily assess acute toxic effects in the short-term, whereas long-term studies for both acute and chronic toxicities designed to evaluate plant biomass and root/shoot elongation over a 2-8 week period (Wang and Liu 2001). These plant bioassays are particularly proper for soil contamination (Boutin et al. 2004). Bacterial bioluminescence assay is also a time-saving, cost-effective test that is widely used for determining the acute toxicities of various type of samples (Wang et al. 2002).

The majority of toxicological studies have mainly focused on the toxicity of single or binary mixture chemicals under controlled conditions (Pavlaki et al. 2011). In practice, the environment is contaminated to various mixtures of chemicals. As such, studies on environmental samples may better reflect pollution of ecosystems and thus could assist in identifying ecologically relevant criteria. Unfortunately, determining the responses of organisms exposed to more than one chemical is one of the most difficult tasks in environmental risk assessment (Norwood et al. 2003). In addition to biotic responses to contaminants, abiotic characteristics of soil can strongly affect the bioavailability and toxicity of contaminants in soil. Many chemical and biochemical processes such as precipitation-dissolution, adsorption-desorption, and oxidation-reduction are critical processes in the control of bioavailability and mobility of metals in soil. The mobility of metals depends not only on their total concentrations in soil but also on soil properties [e.g., soil $\mathrm{pH}$, particle size, organic matter content, redox potential, cation exchange capacity (CEC)], metal properties, and environmental factors (He et al. 2005). Metals present in various forms as water-soluble, exchangeable, oxide-bound, carbonate-bound, organic matter-bound, residual bound to resistant minerals (silicates), display variable mobility and bioavailability (Han et al. 2000). Water-soluble and exchangeable fractions are readily released into the environment, whereas residual fractions are immobile under natural conditions. Several studies have addressed the effects of soil factors on $\mathrm{Cu}$ and $\mathrm{Ni}$ toxicity on plant growth (Rooney et al. 2006; Li et al. 2013). For example, Warne et al. (2008) reported that soil $\mathrm{CEC}$ and $\mathrm{pH}$ are important soil factors for predicting $\mathrm{Cu}$ phytotoxicity across soils. Since metals are important global environmental contaminants, it is important to assess their effects by appropriate bioassays examining their soil properties for any risk assessment.

The purpose of this investigation was as follows: (1) to evaluate the toxicity of soils using different bioassays, (2) to examine possible relationships between the observed toxicity and metal contents (total and acid-extracted) or soil properties. The observed information may improve our understanding for risk assessment of metal-contaminated sites.

\section{Results}

\section{Characteristics of metal contents of tested soils}

Total and $0.1 \mathrm{~N} \mathrm{HCl}$ acid-extracted metal concentrations of tested soils were presented in Table 1. Results showed that six metal concentrations in soil were approximately in the ranges of $127-920$ and $1.03-23.02 \mathrm{mg} / \mathrm{kg}$ soil for total and acid-extracted fractions, respectively. More specifically, metal concentrations of soils were in the following ranges for total (1-627 mg As, 41-117 mg Zn, 40-265 mg Cr, 32-59 mg Pb, 12-95 mg Cu, and $1 \mathrm{mg} \mathrm{Cd}$ per kg dry soil) and acid-extracted (0.13-15.72 mg As, 0.5-6.51 mg Zn, 0.19-6.58 mg Cr, 0-4.60 mg Pb, 0.17$2.45 \mathrm{mg} \mathrm{Cu}$, and $0.05-0.16 \mathrm{mg} \mathrm{Cd}$ per kg dry soil) fractions. Among the 11 samples, four (\#A, B, C, D, K) were highly contaminated with high levels of arsenic within the range of 381-627 mg As $/ \mathrm{kg}$ dry soil. Percentage distributions of the acid-extracted metal fraction were in the range of min. $0.3 \%$ to max. $6.3 \%$ (avg. $1.4 \%$ ) of total contents, depending on the sample site. Low correlation $\left(r^{2}=0.1864\right)$ was observed between contents of total and acid-extracted metals.

\section{Effects of soils on bioluminescence activity}

Figure 1a illustrated the effects of soil extractants in the tested bioassays based on total bioluminescence activity. Control (no exposure to soil) produced a total bioluminescence of approximately $3500 \pm 116 \mathrm{RLU}$ during $1.5 \mathrm{~h}$ of incubation. Bioluminescence activity was in the range of min. $55 \%(1832 \pm 55$ RLU $)$ to max. $118 \%$ (3916 $\pm 155 \mathrm{RLU}$ ) of control during $1.5 \mathrm{~h}$ of exposure, depending on soil type. In general, sudden changes in bioluminescence activity were observed after exposure to extractants. For example, \#B and \#D samples showed elevated bioluminescence activities from 81 to 107 and 65 to $111 \%$ of control after $1.5 \mathrm{~h}$ of exposure, respectively. In contrast, \#A and \#G samples showed inhibited bioluminescence activity from 115 to 75 and 91 to $51 \%$ of control, respectively. Correlations between effects of soil extractants on bioluminescence activity and soil characteristics [metal contents (total and acid-extracted) or physicochemical characteristics (CEC, $\mathrm{pH}, \mathrm{DOC}$, and 
Table 1 Total and weak acid-extracted metal concentrations of tested soil samples

\begin{tabular}{llllllll}
\hline Samples & \multicolumn{2}{l}{ Metals (mg/kg dry soil) (total/acid-extracted) } & & & & \\
\cline { 2 - 7 } & As & Cd & Cu & Pb & Zn & Cr & Sum \\
\hline \#A & $627 / 15.72^{\text {a }}$ & $1 / 0.14$ & $58 / 1.90$ & $55 / 0.18$ & $113 / 2.57$ & $66 / 0.42$ & $920 / 20.9(2.3 \%)^{b}$ \\
\#B & $566 / 0.32$ & $1 / 0.09$ & $45 / 1.71$ & $52 / 2.63$ & $99 / 1.44$ & $59 / 0.98$ & $822 / 7.2(0.9 \%)$ \\
\#C & $381 / 13.31$ & $1 / 0.16$ & $32 / 2.08$ & $45 / 1.78$ & $79 / 4.05$ & $54 / 1.68$ & $592 / 23.0(3.9 \%)$ \\
\#D & $433 / 0.16$ & $1 / 0.05$ & $83 / 0.60$ & $48 / 1.95$ & $117 / 0.63$ & $57 / 0.69$ & $739 / 4.1(0.6 \%)$ \\
\#E & $169 / 0.05$ & $1 / 0.05$ & $54 / 0.17$ & $36 / n d$ & $100 / 0.62$ & $56 / 0.19$ & $416 / 1.1(0.3 \%)$ \\
\#F & $1 / 0.16$ & $1 / 0.06$ & $20 / 1.07$ & $37 / 4.60$ & $92 / 6.51$ & $65 / 1.25$ & $216 / 13.6(6.3 \%)$ \\
\#G & $1 / 0.21$ & $1 / 0.06$ & $18 / 0.33$ & $44 / 1.31$ & $98 / 1.01$ & $45 / 0.20$ & $207 / 3.1(1.5 \%)$ \\
\#H & $1 / 0.16$ & $1 / 0.05$ & $95 / 0.45$ & $42 / 3.81$ & $77 / 0.67$ & $106 / 1.18$ & $322 / 6.3(2.0 \%)$ \\
\#I & $1 / 0.13$ & $1 / 0.06$ & $12 / 0.20$ & $32 / 0.72$ & $41 / 0.94$ & $40 / 0.27$ & $127 / 2.3(1.8 \%)$ \\
\#J & $1 / 0.13$ & $1 / 0.05$ & $13 / 0.17$ & $44 / 1.34$ & $60 / 0.5$ & $102 / 0.36$ & $221 / 2.5(1.2 \%)$ \\
\#K & $401 / 0.32$ & $1 / 0.10$ & $47 / 2.45$ & $59 / 0.62$ & $54 / 2.61$ & $265 / 1.25$ & $827 / 7.4(0.9 \%)$ \\
\hline
\end{tabular}

a Total and acid-extracted concentrations of each metal

${ }^{b}$ Concentration of six metals: total/acid-extracted/\% of acid-extracted to total contents

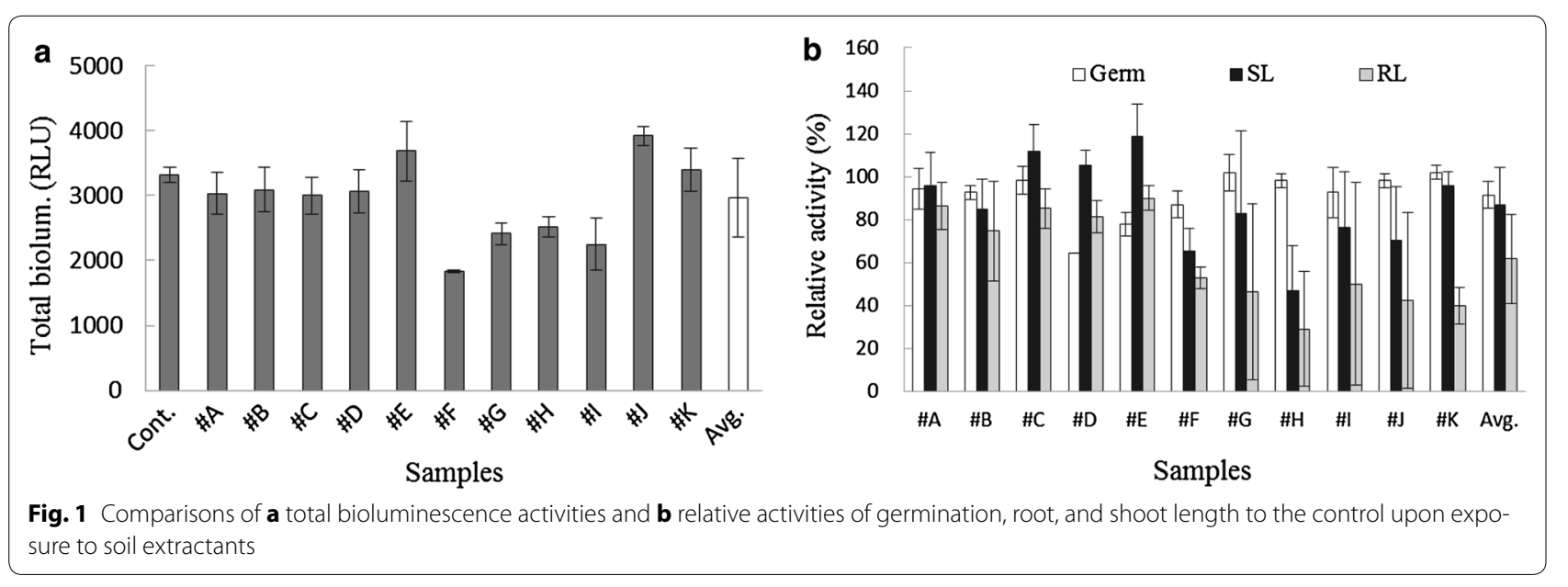

organics)] were examined. No considerable correlations $\left(\mathrm{r}^{2}\right.$ values $\left.<0.1025\right)$ were observed between metal contents (total and acid-extracted) and effects on bioluminescence activity. However, reasonable correlations were observed with DOC and organics, which showed $r^{2}$ values of 0.4973 and 0.7198 , respectively (Fig. 2). Other soil properties such as $\mathrm{pH}$ and CEC showed no considerable correlations with bioluminescence activity $\left(r^{2}<0.096\right)$.

\section{Effects of soils on seed germination}

In the control (no sample treatment), an average of $18 \pm 1.7$ seeds per batch of 20 seeds was germinated (greater than 2-cm growth) during the 3-day incubation period. Unlike the effects on bioluminescence activity (55-118\% of control), the percentage of seeds germinated in the presence of samples was in the range

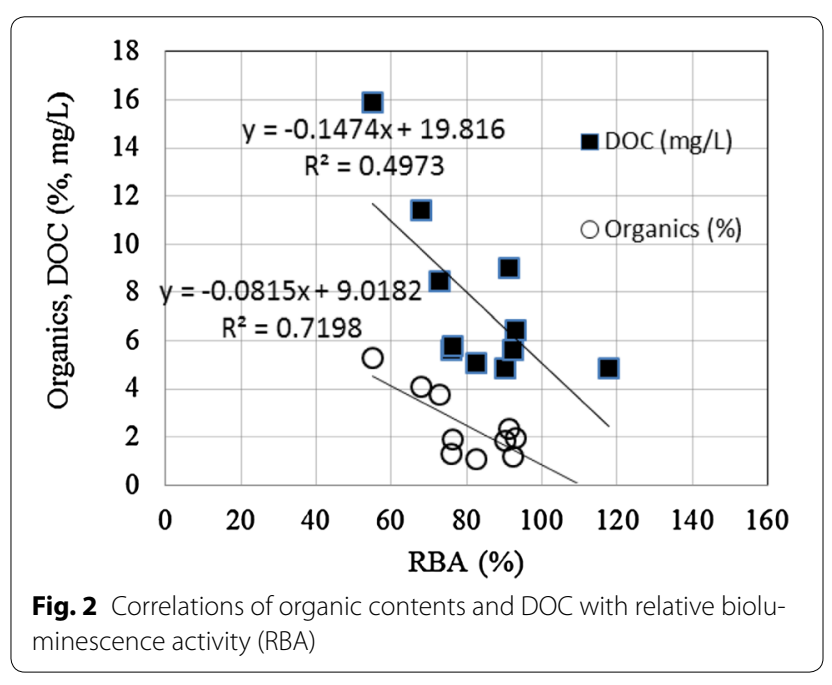


of $64-102 \%$ of control (average $84 \pm 26.6 \%$ ) (Fig. 1b). Correlations between effects of soil extractants on seed germination and soil properties were also examined. Overall, no significant correlations between seed germination by soil extractants and soil properties $(\mathrm{CEC}, \mathrm{pH}$, DOC, and organics) were observed. All cases showed no considerable correlations, with $\mathrm{r}^{2}$ values in the range of $10^{-6}$ (DOC) to 0.0052 (total metal contents).

\section{Effects of soils on root and shoot growth}

Effects on relative root length (RRL) and relative shoot length (RSL) of Lactuca were measured in the metalcontaminated soils. Root and shoot lengths of the control ranged from 44-46 and 31-33 mm, respectively, depending on the batch. Of the tested soils, RSL and RRL were in the ranges of 47-119 and 29-90\%, respectively (Fig. 1b). RSL and RRL of the \#H soil sample were 47 and $29 \%$ of control, respectively, which represents the most prominent reduction. On the other hand in the \#E sample, RSL and RRL were 119 and $90 \%$ of control, respectively, which represents the least effect. Average effects on RSL and RRL were $85 \pm 21.4$ and $60 \pm 22.2 \%$, respectively. Results of the correlation coefficient are presented on Table 2 . Low correlations (less than approximately $\mathrm{r}^{2}$ value 0.27 for both) were observed between total metal contents and their effects on RRL and RSL, and correlations were even lower with acid-extracted contents $\left(\mathrm{r}^{2}\right.$ value 0.169 for RRL, 0.0404 for RSL). However, interestingly, RRL was positively correlated with CEC, showing an $r^{2}$ value of 0.6676. RSL also showed reasonable correlation with CEC compared to other properties with an $r^{2}$ value of 0.3288 , although it was slightly lower than that for RRL. Neither RRL nor RSL showed significant correlations with $\mathrm{pH}, \mathrm{DOC}$, and organics, showing $\mathrm{r}^{2}$ values ranging from 0.0182 to 0.1479 . A positive correlation between RRL and $\operatorname{RSL}\left(r^{2}=0.6849\right)$ was observed for the tested soil samples containing a wide concentration range for all metals.

\section{Effect of extraction ratios (soil:water) on toxicity}

Effects of extractants obtained at different ratios of soil to water (1:6 and 1:3) were compared based on the results of tested bioassays. Metal concentrations of water-extracted solution were very low $(\mu \mathrm{g} / \mathrm{L}$ level), and no considerable differences were found between the two conditions (1:6 and 1:3). Total concentrations of all six metals showed lower than $500 \mu \mathrm{g} / \mathrm{L}$ (data not shown) in the water extractants. In the case of arsenic, 1:6 and 1:3 ratios resulted in concentrations of 75 and $108 \mu \mathrm{g} / \mathrm{L}$ for sample \#C (total $381 \mathrm{mg} / \mathrm{kg}$ dry soil) as well as 70 and $80 \mu \mathrm{g} / \mathrm{L}$ for sample \#A (total $627 \mathrm{mg} / \mathrm{kg}$ dry soil), respectively (Fig. 3). Total arsenic contents of all samples were 252 and $243 \mu \mathrm{g} / \mathrm{L}$ at 1:6 and 1:3 ratio, respectively. The average results of each bioassay, and correlations and statistical significances between the two results, are shown in Table 3. No statistical significant differences between the two results were observed in cases of bioluminescence activity, seed germination, and root growth ( $p$ value $>0.1720$ ). However, only statistical significant difference ( $p$ value 0.0191 ) was observed for shoot growth, which showed $105 \pm 37.3$ and $87 \pm 21.4 \%$ of RSL for 1:3 and 1:6 ratios, respectively. Results of two conditions showed a correlation in the range of 0.4587 to 0.6769. All relative activities to control were above $83 \%$, although low activities were observed for root growth (62 and $58 \%$ at $1: 6$ and $1: 3$ ratios, respectively).

\section{Discussion}

Metals such as $\mathrm{Cu}, \mathrm{Cd}, \mathrm{Cr}, \mathrm{Pb}, \mathrm{As}$, and $\mathrm{Zn}$ are all potential soil pollutants, and a wide range of these elements enters the environment through many sources, including industrial processes, mining, and irrigation (Liu et al. 2007). Tested soils, containing various ranges of metals, collected from nearby groundwater well collection sites. Leaching activities from these sites may have significance effects on groundwater quality and subsurface environments. Total metal contents of tested soils, excluding arsenic, were in the following order: $\mathrm{Zn}, \mathrm{Cr}>\mathrm{Pb}$, $\mathrm{Cu} \gg \mathrm{Cd}$. Arsenic content was in the range of 1-627 mg/ $\mathrm{kg}$ soil and was highly variable depending on the site (Table 1). These metal concentrations were often higher than maximum permissible contents based on two standards in Korea (Jung 2001). As generally known by other investigators, cadmium displayed the lowest content.

Metal contents by weak acid $(0.1 \mathrm{~N} \mathrm{HCl})$ extraction were in the range of $0.3-6.3 \%$ of total contents

Table 2 Summary of correlation coefficients between the activity of each bioassay and soil property

\begin{tabular}{llllllll}
\hline Parameters & \multicolumn{2}{l}{ Correlation coefficients $\left(\mathbf{r}^{\mathbf{2}}\right)$} & & & \\
\cline { 2 - 8 } & Total contents & Acid extracted & CEC & pH & DOC & Organic-C & Organics \\
\hline Bioluminescence & 0.103 & $<0.001$ & 0.095 & 0.096 & 0.497 & 0.720 & 0.720 \\
Seed germination & 0.022 & 0.052 & 0.031 & 0.048 & $0-06$ & 0.011 & 0.011 \\
Root growth & 0.279 & 0.169 & 0.668 & 0.086 & 0.028 & 0.018 & 0.018 \\
Shoot growth & 0.272 & 0.040 & 0.329 & 0.121 & 0.150 & 0.054 & 0.054 \\
\hline
\end{tabular}




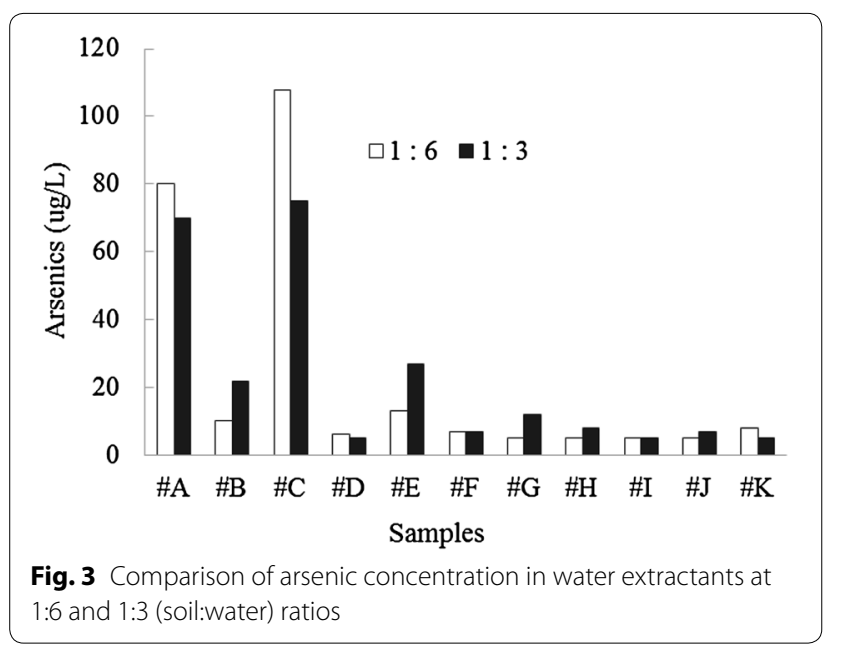

Table 3 Comparisons of toxicities, correlations, and statistical significances between two conditions (soil to water ratio $1: 3$ and $1: 6)$

\begin{tabular}{lccll}
\hline Methods & \multicolumn{2}{l}{$\begin{array}{l}\text { Average activity }(\%) \\
\text { (soil to water ratio) }\end{array}$} & $\begin{array}{l}\text { Correlation }\left(\mathbf{r}^{\mathbf{2}}\right) \\
\text { between } \mathbf{t w o} \\
\text { ratios }\end{array}$ & $\begin{array}{l}\text { Statistics } \\
(\boldsymbol{p} \text { value })\end{array}$ \\
\cline { 2 - 3 } & $\mathbf{1 : 3}$ & $\mathbf{1 : 6}$ & & \\
\hline $\begin{array}{c}\text { Biolumines- } \\
\text { cence }\end{array}$ & $92 \pm 33.6$ & $83 \pm 16.5$ & 0.4587 & 0.1720 \\
$\begin{array}{c}\text { Seed germina- } \\
\text { tion }\end{array}$ & $95 \pm 13.8$ & $92 \pm 11.4$ & 0.6646 & 0.3393 \\
$\begin{array}{c}\text { Root growth } \\
\text { Shoot growth }\end{array}$ & $58 \pm 23.0$ & $62 \pm 22.1$ & 0.6246 & 0.4739 \\
\hline
\end{tabular}

(average $1.4 \%$ ), depending on the site. A low correlation $\left(\mathrm{r}^{2}=0.186\right)$ between total and acid-extracted contents was observed. High percentage of $\mathrm{Cd}$ was found in the acid extractants, showing an average of $7.9 \%$. However, total concentrations of $\mathrm{Cd}$ in these soils were very low $(\sim 1.0 \mathrm{mg} / \mathrm{kg}$ soil), which means the corresponding absolute $\mathrm{Cd}$ concentrations in acid extractants were also very low (average $0.87 \mathrm{mg} / \mathrm{kg}$ soil). Percentage of acid extractants may vary according to soil characteristics, such as $\mathrm{pH}$, organic contents, redox potential, as well as metal properties. Sample \#F, which showed the highest percentage $(6.3 \%)$ of acid extraction, contained high contents of organics and DOC (5.31\% and $15.87 \mathrm{mg} / \mathrm{L}$, respectively), whereas sample \#E showing the lowest percentage $(0.3 \%)$ of acid extraction contained a low content of organics and DOC $(1.09 \%$ and $5.08 \mathrm{mg} / \mathrm{L}$, respectively) compared to other samples. Correlation of acid extractant contents (\% of total content) with organics (\%), organic-C (\%), and DOC showed $r^{2}$ values of $0.3972,0.3971$, and 0.4866 , respectively, whereas there were no observable correlations with soil properties such as $\mathrm{pH}$ and CEC, showing $\mathrm{r}^{2}$ values of 0.2084 and 0.0021 , respectively. These results may be attributed to extraction of organic complex fraction metals by $0.1 \mathrm{~N} \mathrm{HCl}$. The distribution of fractions is an important parameter for determination of metal availability in soils. The organic fraction released in the oxidizable fraction is not considered to be very mobile or available since it is associated with stable high molecular weight humic substances, which slowly release small amounts of metals (Ure and Davidson 2001). Many research studies have also suggested that soil reactions, organic matter contents, and composition of the finest fraction may influence the mobility of metals in the environment (Venditti et al. 2000; Agnieszka et al. 2014). In this study, metal contents of water extractants, which close to exchangeable fraction in nature, were measured prior to the bioassays. Total metal contents of water extractants were very low, sometimes lower than the instrument detection limit, and less than $0.5 \mathrm{mg} / \mathrm{L}$ $(<0.05 \%$ of total contents) for all tested soils regardless of the soil to water ratio.

Kungolos et al. (2009) reported that the toxicity of single compounds varied up to two orders of magnitude, depending on the bioassay examined. Therefore, the combined results of different bioassays will better reflect effects in contaminated soils. In this study, various patterns appeared depending on the types of samples and bioassays (bacterial bioluminescence, seed germination, root, and shoot growth). In the case of bioluminescence, either inhibition or stimulation was observed with no complete inhibition during exposure periods. Relative bioluminescence activity (\%) was in the range of max. $118 \%$ and min $55 \%$ of control (average $82 \pm 16.4 \%$ ). Bioluminescence activity was considerably correlated with organic-C (\%) $\left(r^{2}=0.7204\right)$ rather than with total and acid-extracted metal contents. For example, total metal contents of the \#A and \#F samples were 920 and $216 \mathrm{mg} /$ $\mathrm{kg}$ soil, which were $91 \%$ (9 \% toxicity) and $55 \%$ (45\% toxicity) of relative bioluminescence activity, respectively. This correlation might be attributable to the effects of organics themselves or the bioavailability of organicmetal complexes.

Liu et al. (2005) reported that seed germination is one of the best known indicators of plant development among other endpoints, including root length, shoot height, root biomass, shoot biomass, and total biomass. In contrast, Kapustka et al. (1995) reported germination as the least effective technique for vegetative response endpoints. In this study, seed germination was less sensitive than both root and shoot growth. Inhibition of specific enzymatic reactions by metals permeated into seed reserves is one of the main mechanisms behind metal toxicity on seed germination. In addition, seed germination activities of samples did not show any observable 
correlation with soil properties or metal contents, as all correlation coefficients were less than 0.0607. Effects on root and shoot growth, especially root growth, were clearly greater than that on seed germination (Table 3 ). Average root growth $(62 \pm 22.1 \%)$ was nearly 0.75 to 0.67 times lower than bioluminescence activity, seed germination, and shoot growth $(83 \pm 16.5,92 \pm 11.4$, and $87 \pm 21.4 \%$, respectively). In general, an increase in metal concentration leads to reduction of root and shoot growth in plants. Therefore, root and shoot growth of germinated seeds are likely more affected by metals than seed germination itself. Differences between root and shoot toxicity might be due to the movement of metals from roots to shoots as well as direct contact with the root surface. As metals tend to be retained in root tissues, the effects are generally greater in roots than in shoots (An et al. 2004). Liu et al. (2007) also reported that plant measures are inhibited in the following order: root length $>$ shoot height $>$ biomass $>$ germination frequency. Similar to reports, root growth was clearly more sensitive than shoot growth in all samples (An et al. 2004; Liu et al. 2005). RRL and RSL showed a positive correlation $\left(r^{2}=0.6849\right)$ regardless of the sample characteristics, indicating a reduction in the shoot growth strongly depended on the reduction of root growth.

Research has demonstrated that the toxicity and bioavailability of metals in soils can be strongly influenced by variations in soil chemical and physical properties (Langdon et al. 2014). The specific soil properties that have been shown to play the greatest roles in controlling toxicity, bioavailability, partitioning, and speciation of metals include $\mathrm{pH}$, clay content, organic carbon, and CEC (Smolders et al. 2004; Oorts et al. 2006; Rooney et al. 2007; Criel et al. 2008; Heemsbergen et al. 2009; Li et al. 2011). In this investigation, no considerable correlation was observed between metal contents (total and acid extractants) and any results of the tested methods, showing all $\mathrm{r}^{2}$ values less than 0.2788 . However, specific soil properties were considerably correlated with certain bioassays. Bioluminescence activity was highly correlated with organic-C (\%), showing a correlation coefficient of $\mathrm{r}^{2}$ 0.7204. In contrast, root growth was highly correlated with $\mathrm{CEC}$, showing a correlation coefficient of $r^{2}=0.6676$, whereas correlations with other soil properties were in the range of $0.0183-0.2788$. Shoot growth also showed a little high correlation $\left(r^{2}=0.3288\right)$ with CEC. Both RSL and RRL showed a better correlation with total metal contents $\left(r^{2}=0.2723,0.2788\right)$ compared to other observations, showing $\mathrm{r}^{2}$ values of 0.1025 for bioluminescence and 0.0104 for seed germination. The effects of these soil properties on the behavior and availability of metals have been shown to be metal-specific, with different properties, or combinations of properties, having the greatest influence. Due to the complex characteristics of soil, it is difficult to generalize any relationship with toxicity. Li et al. (2013) reported that soil $\mathrm{pH}$ and organic-C are the most important soil properties controlling the effects of $\mathrm{Cu}$ and $\mathrm{Ni}$ toxicity on tomato and Bokchoy shoot growth. Other studies reported that one metal species in a mixture can influence or even decrease uptake of other metals, which may constitute a novel reduction mechanism (Peralta-Videa et al. 2002). Therefore, it seems not possible to apply the relationships between toxicity and soil properties that have been observed for one case to the behavior and availability of other cases.

\section{Conclusion}

In conclusion, no considerable relationships were observed between toxicity and metal contents (total and acid-extracted). However, soil organic contents and CEC were found to be the main soil properties responsible for effects on bioluminescence activity and root growth, respectively. These factors might be directly related to the toxic effects or indirectly by increasing the bioavailability of contaminants. This result also indicated that root growth was a more sensitive measure of toxicity of contaminated soil, compared to other tested methods (bacterial bioluminescence activity, seed germination, and shoot growth). Overall, the effects of soils were difficult to generalize since they were dependent on many factors, such as metal contents, metal types, soil properties, and the organism used in each bioassay. However, this result suggested that, due to the different sensitivity of each bioassay, a battery of bioassays as opposed to just a single assay was a better strategy for assessment of environmental samples. In addition, observable correlations between specific toxicity and soil properties could be used as valuable information for soil assessments and prediction of toxicity in soils with a wide range of physicochemical properties.

\section{Methods}

\section{Soil collection and metal contents}

Soil samples were collected from 11 different sites in Korea near groundwater collection wells for drinking water. Five samples from each site were collected, and the mixture was used as a test soil sample. In the laboratory, soil samples were dried at ambient temperature (22$25^{\circ} \mathrm{C}$ ), crushed in a porcelain mortar, and sieved through a 2-mm screen. The air-dried samples were then stored in cloth bags for subsequent analysis. General soil properties are shown in Table 4. Total and $0.1 \mathrm{~N} \mathrm{HCl}$ acidextracted metal $(\mathrm{Cu}, \mathrm{Cd}, \mathrm{Cr}, \mathrm{Pb}, \mathrm{Zn}$, and $\mathrm{As})$ contents of soils were quantified by using Flame Atomic Absorption Spectrometry (AAS, Shimadzu, Japan) or Inductively Coupled Plasma (Perkin Elmer, USA). For toxicity test, 
Table 4 Physicochemical characteristics of tested environmental soils

\begin{tabular}{lllrcc}
\hline Samples & $\begin{array}{l}\text { CEC }(\mathbf{c m o l} / \\
\mathbf{k g})\end{array}$ & $\mathbf{p H}$ & $\begin{array}{l}\text { DOC } \\
(\mathbf{m g} / \mathbf{L})\end{array}$ & $\begin{array}{l}\text { Organic-C } \\
\mathbf{( \% )}\end{array}$ & \multicolumn{1}{l}{$\begin{array}{l}\text { Organics } \\
(\%)\end{array}$} \\
\hline \#A & 22.71 & 6.01 & 9.02 & 1.37 & 2.36 \\
\#B & 14.99 & 5.70 & 6.44 & 1.12 & 1.94 \\
\#C & 17.26 & 5.83 & 4.85 & 1.08 & 1.86 \\
\#D & 11.69 & 5.82 & 5.61 & 0.71 & 1.22 \\
\#E & 13.56 & 8.47 & 5.08 & 0.63 & 1.09 \\
\#F & 8.02 & 5.00 & 15.87 & 3.08 & 5.31 \\
\#G & 5.11 & 5.52 & 8.45 & 2.20 & 3.79 \\
\#H & 7.31 & 5.81 & 5.60 & 0.75 & 1.29 \\
\#I & 3.62 & 5.02 & 11.43 & 2.37 & 4.08 \\
\#」 & 5.52 & 7.73 & 4.88 & -0.18 & -0.30 \\
\#K & 8.21 & 5.49 & 5.81 & 1.11 & 1.92 \\
\hline
\end{tabular}

each sample mixed with water (soil to water 1:6 and 1:3 ratios) was shaken for $6 \mathrm{~h}$, after which the supernatant was used. The toxicity was studied using four bioassays: bacterial bioluminescence activity, seed germination, root growth, and shoot growth.

\section{Toxicity with bioluminescence bioassay}

Ecotoxicity of soil extractants were determined using a bioluminescent mutant strain, Escherichia coli DH5 RB1436. This mutant contains a spontaneously deleted pUCD615 plasmid, which results in translocation of a constitutive promoter in the plasmid into close proximity to the lux-genes (Ko et al. 2012). This E. coli strain (obtained from Dr. R.S. Burlage of the University of Concordia, USA) has the ability to release bioluminescence during its growth phase. Strains were stored at $-70{ }^{\circ} \mathrm{C}$ until needed, at which time they were grown overnight in Luria-Bertanika $\left(\mathrm{LB}^{\mathrm{ka}}\right)$ medium (tryptone $10 \mathrm{~g}$, yeast extract $5 \mathrm{~g}, \mathrm{NaCl} 5 \mathrm{~g}, 2 \mathrm{~N} \mathrm{NaOH} 0.5 \mathrm{~mL}$, kanamycin $50 \mathrm{mg} / \mathrm{L})$ at $27^{\circ} \mathrm{C}$ with shaking $(130 \mathrm{rpm})$. The strains were then diluted to $1: 30$ in $\mathrm{LB}^{\mathrm{ka}}$ medium and allowed to grow until the optical density $\left(\mathrm{OD}_{600}\right)$ was approximately 0.6 . This culture was appropriately diluted with minimum salt medium $\left(\mathrm{MgSO}_{4} \cdot 7 \mathrm{H}_{2} \mathrm{O} 0.2 \mathrm{~g}, \mathrm{CaCl}_{2} 0.1 \mathrm{~g}\right.$, $\mathrm{FeSO}_{4} \cdot 7 \mathrm{H}_{2} \mathrm{O} 0.05 \mathrm{mg}, \mathrm{NaMoO}_{4} \cdot 2 \mathrm{H}_{2} \mathrm{O} 0.05 \mathrm{mg}, \mathrm{K}_{2} \mathrm{HPO}_{4}$ $0.43 \mathrm{~g}, \mathrm{KH}_{2} \mathrm{PO}_{4} 0.23 \mathrm{~g}$ ), and the final optical density for the toxicity test was $\mathrm{OD}_{600}=0.2$. For the bioassay, $1 \mathrm{~mL}$ of the bacterial strain was mixed with $9 \mathrm{~mL}$ of soil extractants and incubated for $1.5 \mathrm{~h}$. Bioluminescence was measured using a Turner 20/20 luminometer (Turner Design Inc., CA), where the maximum detection limit was 9999 relative light units (RLU).

\section{Toxicity with seed germination assay}

Seeds of lettuce (Lactuca sativa L.) were selected based on its importance as a food crop. Prior to the germination test, all seeds were surface-sterilized in $3 \% \mathrm{H}_{2} \mathrm{O}_{2}$ and then rinsed with distilled water. Filter paper was placed on a Petri dish and moistened with $5 \mathrm{~mL}$ of the soil extractants. Controls were maintained by moistening the filter paper with $5 \mathrm{~mL}$ of distilled water. Twenty seeds of each species were then placed on a dish, which was covered by a lid and incubated in the dark at $23 \pm 2{ }^{\circ} \mathrm{C}$. Germinated seeds were counted after 3 days of incubation. When both the plumule and radical extended longer than $2 \mathrm{~cm}$ from their junctions, germination was confirmed. Triplicate sets were performed for each treatment.

\section{Toxicity with root and shoot growth bioassay}

Germinated seeds were transferred to serum vials (five germinated seeds per vial) containing $50 \mathrm{~mL}$ of soil extractant solution. The vials were then placed in plant incubator at $25^{\circ} \mathrm{C}$ for 4 days. Following incubation, shoot and root lengths were measured from the root-shoot junction to the longest tip. Root and shoot lengths of seedlings grown in test solutions were expressed as the percentage inhibition (\%) of RRL and RSL compared with the control.

\section{Statistical analysis}

Each of the experimental values was compared to its corresponding control. Statistical significance between different samples was accepted when the probability of the result assuming the null hypothesis $(p)$ was less than 0.05 . Statistical analysis of experimental groups utilized Student's $t$ test (http://www.graphpad.com).

\section{Authors' contributions}

I-MK analyzed the data, wrote part of the manuscript, and conducted some of the experiments. ICK designs the experiments and wrote part of the manuscript with I-MK. Both authors read and approved the final manuscript.

\section{Author details}

'Mineral Resources Department, Korea Institute of Geoscience and Mineral Resources, Daejeon 34132, Korea. ${ }^{2}$ Department of Environmental Engineering, Yeungnam University, Kyungbuk 38541, Korea.

\section{Acknowledgements}

This research was supported by the Basic Research Project of the Korea Institute of Geoscience and Mineral Resources (KIGAM) funded by the Ministry of Science, ICT and Future Planning of Korea.

\section{Competing interests}

The authors declare that they have no competing interests.

\section{Ethical approval}

This research was not involving any of human and animal participants.

Received: 1 July 2015 Accepted: 12 February 2016

Published online: 03 March 2016 


\section{References}

Agnieszka B, Tomasz C, Jerzy W (2014) Chemical properties and toxicity of soils contaminated by mining activity. Ecotoxicology 23:1234-1244

Alvarenga P, Palma P, Goncalves AP, Frnandes RM, de Varennes A, Vallini G, Duarte E, Cunha-Queda AC (2008) Evaluation of tests to assess the quality of mine-contaminated soils. Environ Geochem Health 30:95-99

An YJ, Kim YM, Kwon Yl, Jeong SW (2004) Combined effect of copper, cadmium, and lead upon Cucumis sativus growth and bioaccumulation. Sci Total Environ 326:857-863

Banks MK, Schultz KE (2005) Comparison of plants for germination toxicity tests in petroleum-contaminated soils. Water Air Soil Pollut 167:211-219

Boutin C, Elmegaard N, Kjaer C (2004) Toxicity testing of fifteen non-crop plant species with six herbicides in a greenhouse experiment: implications for risk assessment. Ecotoxicology 13:349-369

Criel P, Lock K, van Eeckhout H, Oorts K, Smolders E, Janssen CR (2008) Influence of soil properties on copper toxicity for two soil invertebrates. Environ Toxicol Chem 27(8):1748-1755

Di Salvatore M, Carafa AM, Carratu G (2008) Assessment of heavy metals phytotoxicity using seed germination and root elongation tests: a comparison of two growth substrates. Chemosphere 73(9):1461-1464

Han FX, Kingery WL, Selim HM, Derard PD (2000) Accumulation of heavy metals in a long-term poultry waste-amended soil. Soil Sci 165(3):260-268

He ZL, Yang XE, Stoffella PJ (2005) Trace elements in agroecosystems and impacts on the environment. J Trace Elem Med Biol 19(2-3):125-140

Heemsbergen DA, Warne MSJ, Broos K, Bell M, Nash D, McLaughlin M, Whatmuff M, Barry G, Pritchard D, Penney N (2009) Application of phytotoxicity data to a new Australian soil quality guideline framework for biosolids. Sci Total Environ 407:2546-2556

Jung MC (2001) Heavy metal contamination of soils and waters in and around the Imcheon Au-Ag mine, Korea. Appl Geochem 16:1369-1375

Kapustka LA, Lipton J, Galbraith H, Cacela D, Lejeune K (1995) Metal and arsenic impacts to soils, vegetation communities and wildlife habitat in Southwest Montana uplands contaminated by smelter emissions: II. Laboratory phytotoxicity studies. Environ Toxicol Chem 14(11):1905-1912

Ko KS, Lee PK, Kong IC (2012) Evaluation of the toxic effects of arsenite, chromate, cadmium, and copper using a battery of four bioassays. Appl Microbiol Biotechnol 95:1343-1350

Kungolos A, Emmanouil C, Tsiridis V, Tsiropoulos N (2009) Evaluation of toxic and interactive toxic effects of three agrochemicals and copper using a battery of microbiotests. Sci Total Environ 407:4610-4615

Langdon KA, McLaughlin MJ, Kirby JK, Merrington G (2014) The effect of soil properties on the toxicity of silver to the soil nitrification process. Environ Toxicol Chem 33(5):1170-1178

Leitgib L, Kalman J, Gruiz K (2007) Comparison of bioassay by testing whole soil and their water extract from contaminated sites. Chemosphere 66(3):428-434

Li B, Zhang H, Ma Y, McLaughlin MJ (2011) Influences of soil properties and leaching on nickel toxicity to barley root elongation. Ecotoxicol Environ Safety 74:459-466

Li B, Zhang H, Ma Y, McLaughlin MJ (2013) Relationships between soil properties and toxicity of copper and nickel to Bok Choy and tomato in Chines soils. Environ Toxicol Chem 32(10):2372-2378

Liu X, Zhang S, Shan X, Zhu YG (2005) Toxicity of arsenate and arsenite on germination, seed growth and amylolytic activity of wheat. Chemosphere 61:293-301

Liu X, Zhang S, Shan X-Q, Christie P (2007) Combined toxicity of cadmium and arsenate to wheat seedlings and plant uptake and antioxidative enzyme responses to cadmium and arsenate co-contamination. Ecotoxicol Environ Saf 68:305-313

Molnar M, Leitgib L, Gruiz K, Fenyvesi E, Szaniszlo N, Szejtli J, Fava F (2005) Enhanced biodegradation of transformer oil in soils with cyclodextrinfrom the laboratory to the field. Biodegradation 16:159-168

Norwood WP, Borgmann U, Dixon DG, Wallace A (2003) Effects of metal mixtures on aquatic biota: a review of observations and methods. Hum Eco Risk Assess 9(4):795-811

Oorts K, Ghesquiere U, Swinnen K, Smolders E (2006) Soil properties affecting the toxicity of $\mathrm{CuCl}_{2}$ and $\mathrm{NiCl}_{2}$ for soil microbial processes in freshly spiked soils. Environ Toxicol Chem 25:836-844

Pavlaki MD, Pereira R, Loureiro S, Soares AM (2011) Effects of binary mixtures on the life traits of Daphnia magna. Ecotoxico Environ Saf 74(1):99-110

Peralta-Videa JR, Gardea-Torresdey JL, Gomez E, Tiermann KJ, Parsons JG, Carrillo GE (2002) Effect of mixed cadmium, copper, nickel and zinc at different pHs upon alfafa growth and heavy metal uptake. Environ Pollut 119:291-301

Plaza G, Nalecz-Jawecki G, Pinyakong O, Illmer P (2010) Ecotoxicological and microbiological characterization of soils from heavy metal and hydrocarbon contaminated sites. Environ Monit Assess 163:477-488

Ravenscroft P, Brammer H, Richards KS (2009) Arsenic pollution: a global synthesis. Wiley-Blackwell, Oxford

Rooney CP, Zhao FJ, McGrath SP (2006) Soil factors controlling the expression of copper toxicity to plants in a wide range of European soils. Environ Toxicol Chem 25(3):726-732

Rooney CP, Zhao FJ, McGrath SP (2007) Phytotoxicity of nickel in a range of European soils: influence of soil properties, Ni solubility and speciation. Environ Pollut 145:596-605

Shivhare L, Sharma S (2012) Effect of toxic heavy metal contaminated soil on an ornamental plant Georgina wild (Dahlia). J Environ Anal Toxicol 2(7):1-3

Smolders E, Buekers J, Oliver I, McLaughlin MJ (2004) Soil properties affecting toxicity of zinc to soil microbial properties in laboratory-spiked and fieldcontaminated soils. Environ Toxicol Chem 23:2633-2640

Ure AM, Davidson CM (2001) Chemical speciation in the environment. Blackie, Glasgow, p 464

US EPA (1993) Methods for measuring the acute toxicity of effluents and receiving waters to freshwater and marine organisms. US Environmental Protection Agency 4th ed. EPA/600/4-90/027F

Venditti D, Durecu S, Berthelin J (2000) A multidisciplinary approach to assess history, environmental risks, and remediation feasibility of soils contaminated by metallurgical activities. Part A: chemical and physical properties of metals and leaching ability. Arch Environ Contam Toxicol 38(4):411-420

Wang X, Liu Y (2001) Validation of germination rate and root elongation as an indicator to assess phytotoxicity with Cucumis sativus. Chemosphere 44:1711-1721

Wang C, Yediler A, Kiefer F, Wang Z, Kettrup A (2002) Comparative studies on the acute toxicities of auxiliary chemicals used in textile finishing industry by bioluminescence test and neutral red test. Bull Environ Contam Toxicol 68:478-484

Warne MSJ, Heemsbergen DA, Stevens D, McLaughlin MJ, Cozens G, Whatmuff M, Broos K, Barry G, Bell M, Nash D, Pritchard D, Penney N (2008) Modeling the toxicity of copper and zinc salts to wheat in 14 soils. Environ Toxicol Chem 27:786-792

Yi H, Wu L, Jiang L (2007) Genotoxicity of arsenic evaluated by Allium-root micronucleus assay. Sci Total Environ 383:232-236 